\title{
Association between serum zinc and copper concentrations and copper/zinc ratio with the prevalence of knee chondrocalcinosis: a cross-sectional study
}

Hongyi He ${ }^{\dagger}$, Yilun Wang ${ }^{\dagger}$, Zidan Yang ${ }^{2}$, Xiang Ding ${ }^{1}$, Tuo Yang ${ }^{3}$, Guanghua Lei ${ }^{1,4,5,6}$, Hui Li $^{1}$ and Dongxing Xie ${ }^{1^{*}}$

\begin{abstract}
Background: Patients with chondrocalcinosis may suffer from a series of symptoms resembling acute gouty arthritis or septic arthritis, but the aetiology and pathogenesis of chondrocalcinosis have not been fully elucidated yet. This study was aimed to assess serum zinc and copper concentrations, as well as the ratio of serum copper to zinc concentrations ( $\mathrm{Cu} / \mathrm{Zn}$ ratio), in relation to the prevalence of knee chondrocalcinosis.

Methods: Data included in this analysis were retrieved from a large population-based cross-sectional study. A bilateral knee anteroposterior radiograph was obtained from each subject. Radiographic knee chondrocalcinosis was diagnosed if definite linear cartilage calcification was detected. Serum zinc and copper concentrations were measured using the spectrophotometric flow injection methods by Roche modular P800. The relations of serum zinc and copper concentrations and $\mathrm{Cu} / \mathrm{Zn}$ ratio to the prevalence of knee chondrocalcinosis were examined using generalized estimating equations, respectively.

Results: The prevalence of knee chondrocalcinosis was $1.2 \%$ in the sample of this study $(n=12,362)$. In comparison with the lowest tertile, the odds ratios (ORs) of knee chondrocalcinosis adjusted by age, sex and body mass index were 0.74 (95\% Cl 0.50-1.09) in the second and 0.56 (95\% Cl 0.36-0.86) in the third tertiles of serum zinc concentrations ( $P$ for trend $=0.009)$, were $1.26(95 \% \mathrm{Cl} 0.77-2.05)$ in the second and $2.01(95 \% \mathrm{Cl} 1.25-3.24)$ in the third tertile of serum copper concentrations ( $P$ for trend $=0.003$ ), and were $1.02(95 \% \mathrm{Cl} 0.61-1.69)$ in the second and $2.23(95 \% \mathrm{Cl} 1.38-3.59)$ in the third tertile of $\mathrm{Cu} / \mathrm{Zn}$ ratio $(P$ for trend $<0.001)$ respectively. These findings were not materially altered by adjustment for potential confounders.

Conclusions: The present study observed that higher serum zinc concentrations, lower serum copper concentrations or lower $\mathrm{Cu} / \mathrm{Zn}$ ratio are associated with a lower prevalence of knee chondrocalcinosis in a doseresponse relationship manner.
\end{abstract}

Keywords: Zinc, Copper, Chondrocalcinosis

\footnotetext{
* Correspondence: xdx1024@csu.edu.cn

${ }^{\dagger}$ Hongyi He and Yilun Wang contributed equally to this work.

'Department of Orthopaedics, Xiangya Hospital, Central South University, \#87

Xiangya Road, Changsha 410008, Hunan Province, China

Full list of author information is available at the end of the article
}

(c) The Author(s). 2020 Open Access This article is distributed under the terms of the Creative Commons Attribution 4.0 International License (http://creativecommons.org/licenses/by/4.0/), which permits unrestricted use, distribution, and reproduction in any medium, provided you give appropriate credit to the original author(s) and the source, provide a link to the Creative Commons license, and indicate if changes were made. The Creative Commons Public Domain Dedication waiver (http://creativecommons.org/publicdomain/zero/1.0/) applies to the data made available in this article, unless otherwise stated. 


\section{Background}

Chondrocalcinosis is a disease characterized by the formation of calcium pyrophosphate and basic calcium phosphate crystals in the pericellular matrix of cartilage, and by the calcification of articular fibrocartilage and hyaline cartilage [1-3]. Patients with chondrocalcinosis may suffer from fever, joint pain and a series of other clinical symptoms that are similar to acute gouty arthritis or septic arthritis and chronic symptoms resembling osteoarthritis, which all contributes to a compromised quality of life and a worsened comorbidity [4-8]. As for asymptomatic patients, though no clinical symptoms manifested, the crystals deposited on the cartilage surface may cause or accelerate joint damage by activating inflammatory response, altering the mechanical stress distribution on the cartilage surface and acting as wear particles, which was postulated as a condition representing a presymptomatic phase of clinical arthritis $[9,10]$. However, the aetiology and pathogenesis of chondrocalcinosis have not been fully elucidated.

As important trace elements in the human body, zinc and copper are both involved in many homeostatic mechanisms, including immunity and inflammation [11-13]. While zinc was believed to be an antiinflammatory factor, copper was suggested to be a proinflammatory agent $[13,14]$. Previous studies have reported that many common diseases, such as cardiovascular disease, cancer, type 2 diabetes, Alzheimer's disease, vitiligo and multiple sclerosis were associated with lower zinc concentrations and higher copper concentrations, of which the underlying mechanisms were suspected to be attributed to immune function, inflammatory response and oxidative stress [15-20]. In addition, not only is the individual concentrations of serum copper and zinc of concern, but the balance between these two elements appears to be important. Previous studies suggested that calculating the ratio of serum copper to zinc concentrations, hereafter referred to as $\mathrm{Cu} / \mathrm{Zn}$ ratio, provided valuable information in regard to oxidative stress and inflammatory responses [21]. Due to the essential role of inflammatory response in the pathogenesis of chondrocalcinosis [22, 23], it was postulated that there might be a potential link between the serum zinc and copper concentrations, as well as $\mathrm{Cu} / \mathrm{Zn}$ ratio, and the prevalence of chondrocalcinosis. However, to our best knowledge, no study has been performed to investigate these correlations yet.

To fill in the knowledge gap, data were collected from a large population-based cross-sectional study and used to examine the relationship between serum zinc and copper concentrations and $\mathrm{Cu} / \mathrm{Zn}$ ratio with the prevalence of knee chondrocalcinosis so as to determine the shape of the corresponding dose-response relationship if it exists.

\section{Methods}

\section{Study population}

The subjects of this cross-sectional study were individuals from the general population who had undergone routine health examinations at Xiangya Hospital, Central South University in Changsha, Hunan, China, between October 2013 and December 2015. Identical study designs have already been reported in some previous publications [24-26]. Briefly speaking, the routine health checkups include anthropometric measurements (such as height and body mass), basic clinical tests (such as blood pressure and heart rate), biochemistry (such as blood tests, liver function, kidney function and trace element tests) and imaging tests (such as chest radiography and weight-bearing bilateral anterior-posterior knee radiography). The subjects qualified for this study were individuals satisfying the following inclusion criteria: (1) age $\geq 40$ years; (2) completed the serum zinc and serum copper tests; (3) provided bilateral weightbearing anteroposterior and bilateral axial knee X-ray films. Prior to the start of the study, all the involved interviewers, clinical inspectors, and X-ray technicians had been properly trained by the leading researchers.

During the study period, 31,542 participants underwent routine health checkups at the aforementioned study center and 12,420 of them met all the inclusion criteria. Then, 58 participants were eliminated according to the exclusion criteria: (1) the weight-bearing anteroposterior knee radiograph was in unsatisfactory quality $(n=53)$; and (2) the Kellgren-Lawrence (KL) [27] grades of both knees were $4(n=5)$. Eventually, 12,362 participants were included in the final analysis.

\section{Blood biochemical analysis}

The venous blood sample was collected from each subject upon an overnight fast of $12 \mathrm{~h}$ with a serum separation tube (containing silica clot activators and gel separator) and was immediately centrifuged at $4{ }^{\circ} \mathrm{C}$ for $10 \mathrm{~min}$ at 3000 relative centrifugal force. The serum zinc and serum copper concentrations were detected by the spectrophotometric flow injection methods, "2-(5Bromo-2-pyridylazo)-5-[N-propyl-N-(3-sulfopropyl) amino] phenol", i.e., 5-Br-PAPS, and the "4-(3,5dibromo-2-pyridylazo)-N-ethyl-N-(3-sulfopropyl) aniline", i.e., 3,5-diBr-PAESA, respectively, using Roche modular P800 [28-30].

The inter-assay coefficients of variation were $4.44 \%$ $(10.1 \mu \mathrm{mol} / \mathrm{L})$ and $2.50 \%(18.5 \mu \mathrm{mol} / \mathrm{L})$ and the intraassay coefficients of variation were $2.86 \%(18.74 \mu \mathrm{mol} / \mathrm{L})$ and $3.42 \%(9.49 \mu \mathrm{mol} / \mathrm{L})$ for serum zinc. Likewise, the inter-assay coefficients of variation were $6.15 \%$ $(9.8 \mu \mathrm{mol} / \mathrm{L})$ and $4.33 \%(16.5 \mu \mathrm{mol} / \mathrm{L})$, and the intraassay coefficients of variation were $5.17 \%(16.72 \mu \mathrm{mol} / \mathrm{L})$ and $5.37 \%(8.86 \mu \mathrm{mol} / \mathrm{L})$ for serum copper. The 
measuring methods and data reliability of potential confounders (e.g., serum iron, calcium, magnesium and phosphorus) are shown in Additional file 1.

\section{Assessment of radiographic knee chondrocalcinosis}

Two orthopaedic surgeons were engaged to evaluate all the X-ray films while remaining blinded to the clinical and biochemical findings of corresponding subjects. Radiographic chondrocalcinosis was defined by evidence of knee joint linear cartilage calcification [31]. Specifically, prior to the assessment, the two orthopaedic surgeons were requested to review $200 \mathrm{X}$-rays films from the Osteoarthritis Initiative (OAI) for calibration purpose until they had agreed with each other on all these readings to a high level (the cutoff of simple kappa for the inter-rater reliability was 0.70 ). Then, the formal reading process started by reading each batch of knee Xrays in a mixed manner (100 X-rays in one batch: 10 previously-read X-rays and 90 unread X-rays that were randomly selected). The unread radiographs were utilized to test the inter-rater reliability, while the previously-read radiographs were utilized to test the intra-rater reliability. Both surgeons were requested to evaluate all the X-rays, and the inconsistencies, if any, were resolved through discussion. The Kappa value of the X-ray reliability reading was $0.72(95 \%$ CI $0.67-0.77)$ for the inter-evaluator and 0.76 (95\% CI $0.67-0.85)$ for the assessor's internal reliability [24].

\section{Statistical analysis}

The continuous data were expressed in the form of mean \pm standard deviation, and the categorical data were expressed in the form of proportion (percentage). According to the tertile distribution in the study population, the serum zinc and copper concentrations were classified into three categories (i.e., $\leq 12.1,12.2-14.2$, and $\geq 14.3 \mathrm{mmol} / \mathrm{L}$ for zinc; and $\leq 14.7,14.8-17.5$, and $\geq$ $17.6 \mathrm{mmol} / \mathrm{L}$ for copper). $\mathrm{Cu} / \mathrm{Zn}$ ratio was also calculated, and then classified into three categories according to its tertile distribution (i.e., $\leq 1.07,1.08-1.38$, and $\geq$ 1.39). The generalized estimating equation [32] was used to investigate the association of each of the serum zinc, copper and $\mathrm{Cu} / \mathrm{Zn}$ ratio categories with chondrocalcinosis, under adjustment of potential confounders (kneespecificity analysis). The binary distribution and the logit linkage of the PROC GENMOD program in SAS were used to calculate the odds ratio (OR) and the related 95\% confidence interval (95\% CI) of chondrocalcinosis among various serum zinc and copper and $\mathrm{Cu} / \mathrm{Zn}$ ratio categories, with the lowest tertile of serum zinc or copper or $\mathrm{Cu} / \mathrm{Zn}$ ratio being taken as the reference. Specifically, the confounders of age (40-49 years old, 50-59 years old, 60-69 years old, $\geq 70$ years old), body mass index (BMI) $\left(<28, \geq 28 \mathrm{~kg} / \mathrm{m}^{2}\right)$ and sex (male, female) were adjusted first. Then, each of the following covariates: serum iron (tertiles), serum calcium (tertiles), serum magnesium (tertiles), serum zinc (tertiles), serum copper (tertiles) and serum phosphorus (tertiles) was added into the regression model.

Subsequently, the dose-response relationships between the serum zinc and copper concentrations and $\mathrm{Cu} / \mathrm{Zn}$ ratio with the prevalence of knee chondrocalcinosis were plotted by generalized additive models with spline regression [33].

\section{Results}

A total of 12,362 subjects (7017 men and 5345 women) aged $\geq 40$ years (average $52.1 \pm 7.9$ years) were included in the analysis. The prevalence of knee chondrocalcinosis in the entire sample was $1.2 \%$ (Table 1 ).

Figure 1 shows the linear association between the serum zinc and predicted prevalence of chondrocalcinosis. Compared with the lowest tertile of serum zinc, the prevalence of knee chondrocalcinosis decreased by $0.5 \%$ in the middle and $0.9 \%$ in the highest. As shown in model 1, the ORs (95\% CIs) for knee chondrocalcinosis, with adjustment for age, sex and BMI, were 0.74 (95\% CI $0.50-1.09$ ) and 0.56 (95\% CI 0.36-0.86) from the second to the highest tertile of serum zinc, respectively, compared with the lowest tertile ( $P$ for trend $=0.009$ ). With further adjustment for serum iron (model 2),

Table 1 Basic characteristics among 12,362 participants according to knee chondrocalcinosis status

\begin{tabular}{|c|c|c|c|}
\hline & \multicolumn{2}{|c|}{ Chondrocalcinosis status } & \multirow[t]{2}{*}{$P$} \\
\hline & Yes & No & \\
\hline Number & 153 & 12,209 & - \\
\hline Median serum zinc level ( $\mu \mathrm{mol} / \mathrm{L})$ & 12.4 & 13.1 & - \\
\hline Median serum copper level ( $\mu \mathrm{mol} / \mathrm{L})$ & 17.5 & 16.0 & - \\
\hline Median $\mathrm{Cu} / \mathrm{Zn}$ ratio & 1.45 & 1.21 & - \\
\hline Age (years) & $61.7 \pm 10.1$ & $52.0 \pm 7.8$ & $<0.001$ \\
\hline $40-49(\%)$ & 15.0 & 45.2 & \\
\hline $50-59(\%)$ & 27.5 & 37.7 & \\
\hline $60-69(\%)$ & 35.3 & 14.5 & \\
\hline$\geq 70(\%)$ & 22.2 & 2.6 & \\
\hline Gender (\% female) & 45.8 & 43.2 & 0.528 \\
\hline $\operatorname{BMI}\left(\mathrm{kg} / \mathrm{m}^{2}\right)$ & $24.9 \pm 3.5$ & $24.5 \pm 4.0$ & 0.161 \\
\hline$<28 \mathrm{~kg} / \mathrm{m}^{2}(\%)$ & 83.0 & 87.0 & \\
\hline$\geq 28 \mathrm{~kg} / \mathrm{m}^{2}(\%)$ & 17.0 & 13.0 & \\
\hline Serum iron $(\mu \mathrm{mol} / \mathrm{l})$ & $16.7 \pm 5.2$ & $18.5 \pm 6.5$ & $<0.001$ \\
\hline Serum calcium (mmol/l) & $2.4 \pm 0.1$ & $2.4 \pm 0.1$ & 0.609 \\
\hline Serum magnesium (mmol/l) & $0.88 \pm 0.12$ & $0.89 \pm 0.08$ & 0.023 \\
\hline Serum phosphorus (mmol/l) & $1.1 \pm 0.2$ & $1.2 \pm 0.2$ & 0.840 \\
\hline
\end{tabular}

$B M I$ body mass index, Cu/Zn ratio the ratio of serum copper to zinc concentrations

Data are mean \pm standard deviation, unless otherwise indicated 


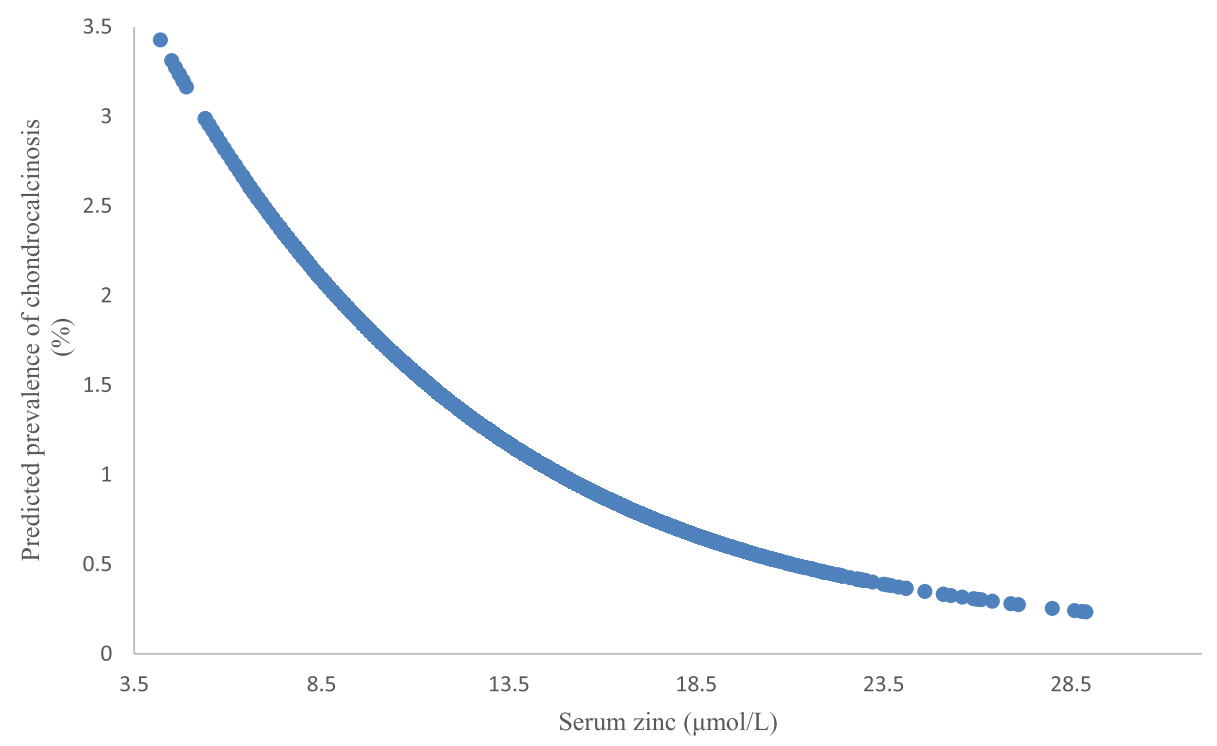

Fig. 1 Association between serum zinc and predictive prevalence of chondrocalcinosis

calcium (model 3), magnesium (model 4), copper (model 5) and phosphorus (model 6) on the basis of model 1, the results were not substantially altered (Table 2).

The dose-response relationship between the serum copper and predicted prevalence of chondrocalcinosis is shown in Fig. 2. The prevalence of knee chondrocalcinosis was $0.8 \%$ in the lowest tertile of serum copper and increased by $0.3 \%$ in the middle and $1.1 \%$ in the highest. The age, sex and BMI adjusted ORs (95\% CIs) for knee chondrocalcinosis were 1.26 (95\% CI 0.77-2.05) and 2.01 (95\% CI 1.25-3.24) from the second to the highest tertile of serum copper, respectively, compared with the lowest tertile $(P$ for trend $=0.003)$ (model 1$)$. The results were not materially changed after further adjustment for potential confounders on the basis of model 1 (Table 3).

Figure 3 illustrates the dose-response relationship between $\mathrm{Cu} / \mathrm{Zn}$ ratio and predicted prevalence of chondrocalcinosis. A positive association between $\mathrm{Cu} / \mathrm{Zn}$ ratio and the prevalence of chondrocalcinosis is illustrated in Table 4. The results did not change substantially after adjustment for potential confounders (i.e., age, sex, BMI, serum iron, serum calcium, serum magnesium and serum phosphorus).

Table 2 Association between serum zinc and knee chondrocalcinosis $(n=12,362)$

\begin{tabular}{|c|c|c|c|c|}
\hline & \multicolumn{3}{|c|}{ Tertiles of serum zinc $(\mu \mathrm{mol} / \mathrm{L})$} & \multirow{2}{*}{$\begin{array}{l}P \text { for } \\
\text { trend }\end{array}$} \\
\hline & $1(\leq 12.1)$ & $2(12.2-14.2)$ & $3(\geq 14.3)$ & \\
\hline \multicolumn{5}{|l|}{ Total } \\
\hline Knee chondrocalcinosis (\%) & 1.7 & 1.2 & 0.8 & - \\
\hline $\mathrm{N}$ for knee ${ }^{a}$ & 8354 & 8285 & 8082 & - \\
\hline Model 1 (95\% Cl) & 1.00 (reference) & $0.74(0.50,1.09)$ & $0.56(0.36,0.86)$ & 0.009 \\
\hline Model 2 (95\% Cl) & 1.00 (reference) & $0.77(0.52,1.14)$ & $0.59(0.38,0.91)$ & 0.018 \\
\hline Model $3(95 \% \mathrm{Cl})$ & 1.00 (reference) & $0.73(0.49,1.08)$ & $0.54(0.35,0.84)$ & 0.006 \\
\hline Model 4 (95\% Cl) & 1.00 (reference) & $0.75(0.51,1.12)$ & $0.56(0.37,0.87)$ & 0.010 \\
\hline Model 5 (95\% Cl) & 1.00 (reference) & $0.75(0.51,1.11)$ & $0.58(0.37,0.88)$ & 0.012 \\
\hline Model 6 (95\% Cl) & 1.00 (reference) & $0.75(0.50,1.11)$ & $0.56(0.37,0.87)$ & 0.011 \\
\hline
\end{tabular}

Model 1 included age (40-49, 50-59, 60-69, $\geq 70$ years), body mass index $\left(<28, \geq 28 \mathrm{~kg} / \mathrm{m}^{2}\right)$ and $\operatorname{sex}(n=12,362)$;

Model 2 added serum iron (tertiles) on the basis of model $1(n=12,357)$;

Model 3 added serum calcium (tertiles) on the basis of model $1(n=12,264)$;

Model 4 added serum magnesium (tertiles) on the basis of model $1(n=12,362)$;

Model 5 added serum copper (tertiles) on the basis of model $1(n=12,362)$;

Model 6 added serum phosphorus (tertiles) on the basis of model $1(n=12,264)$

${ }^{a}$ Three right knees with K-L 4 grade were excluded for analysis (data from the contralateral knees were retained)

$\mathrm{N}$ number, $\mathrm{Cl}$ confidence interval 


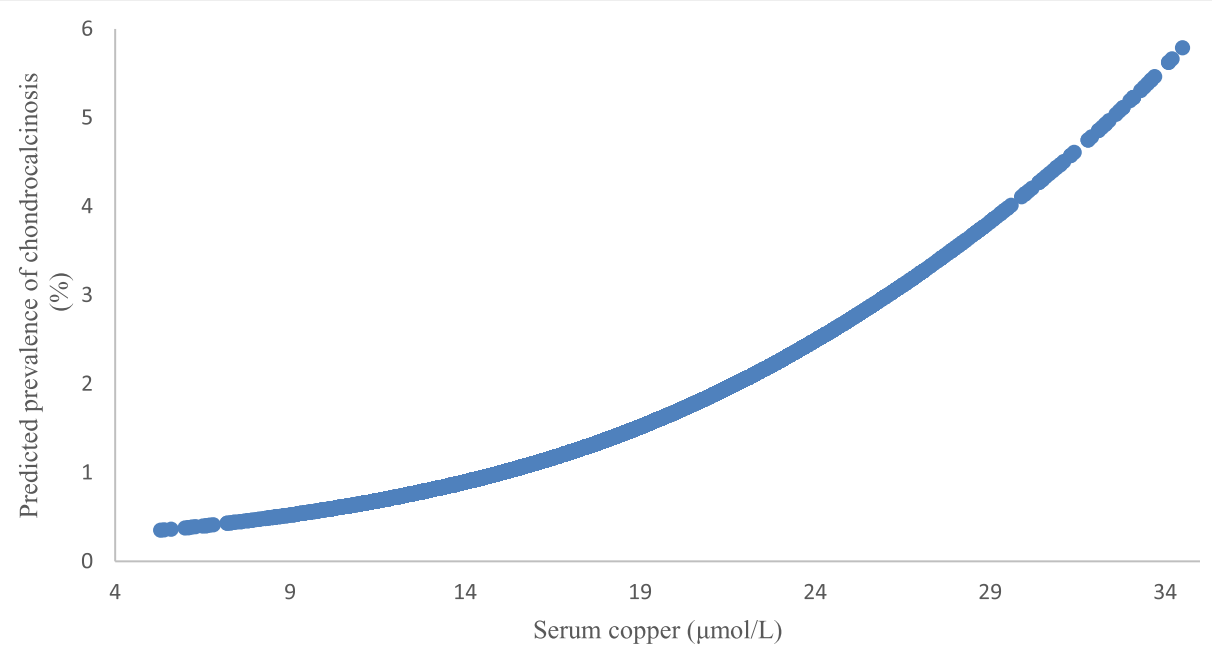

Fig. 2 Association between serum copper and predictive prevalence of chondrocalcinosis

\section{Discussion}

To our best knowledge, this is the first study revealing positive associations between the serum copper, $\mathrm{Cu} / \mathrm{Zn}$ ratio and the prevalence of chondrocalcinosis, as well as an inverse association between the serum zinc and the prevalence of chondrocalcinosis in contrast. Our findings are independent of some major confounders, such as age, sex, BMI, iron, calcium, magnesium, copper, zinc, and phosphorus, suggesting that the observed associations are robust.

While the biological mechanisms of linking the concentrations of serum zinc and copper to the risk of knee chondrocalcinosis are not fully understood, the inflammatory response may partly explain these findings. Zinc deficiency can lead to a proinflammatory status [13]. Previous studies have shown that a lower level of zinc concentration could reduce the natural killer cell immune activity, alter the inflammatory cytokine production, and impair the function of superoxide dismutase which would in turn alleviate the inflammatory response by converting $\mathrm{O}_{2}{ }^{-}$free radicals into $\mathrm{O}_{2}$ and $\mathrm{H}_{2} \mathrm{O}_{2}$ [3438]. On the contrary, a higher level of copper concentration could accelerate the catalytic action of $\mathrm{H}_{2} \mathrm{O}_{2}$ into hydroxyl radicals, which would then strengthen the reactive oxygen species-dependent killing in macrophages and thereby aggravate the inflammatory response [39].

The deposition of calcium pyrophosphate crystals on articular fibrocartilage or hyaline cartilage is one

Table 3 Association between serum copper and knee chondrocalcinosis $(n=12,362)$

\begin{tabular}{|c|c|c|c|c|}
\hline & \multicolumn{3}{|c|}{ Tertiles of serum copper $(\mu \mathrm{mol} / \mathrm{L})$} & \multirow{2}{*}{$\begin{array}{l}P \text { for } \\
\text { trend }\end{array}$} \\
\hline & $1(\leq 14.7)$ & $2(14.8-17.5)$ & $3(\geq 17.6)$ & \\
\hline \multicolumn{5}{|l|}{ Total } \\
\hline Knee chondrocalcinosis (\%) & 0.8 & 1.1 & 1.9 & - \\
\hline$N$ for knee* & 8390 & 8190 & 8141 & - \\
\hline Model $1(95 \% \mathrm{Cl})$ & 1.00 (reference) & $1.26(0.77,2.05)$ & $2.01(1.25,3.24)$ & 0.003 \\
\hline Model $2(95 \% \mathrm{Cl})$ & 1.00 (reference) & $1.26(0.78,2.06)$ & $1.94(1.21,3.12)$ & 0.004 \\
\hline Model $3(95 \% \mathrm{Cl})$ & 1.00 (reference) & $1.24(0.76,2.02)$ & $2.00(1.24,3.23)$ & 0.003 \\
\hline Model $4(95 \% \mathrm{Cl})$ & 1.00 (reference) & $1.27(0.78,2.07)$ & $2.11(1.31,3.38)$ & 0.001 \\
\hline Model $5(95 \% \mathrm{Cl})$ & 1.00 (reference) & $1.22(0.75,1.99)$ & $1.95(1.21,3.12)$ & 0.004 \\
\hline Model 6 (95\% Cl) & 1.00 (reference) & $1.24(0.76,2.02)$ & $2.00(1.24,3.22)$ & 0.003 \\
\hline
\end{tabular}

Model 1 included age $\left(40-49,50-59,60-69, \geq 70\right.$ years), body mass index $\left(<28, \geq 28 \mathrm{~kg} / \mathrm{m}^{2}\right)$ and sex $(n=12,362) ;$

Model 2 added serum iron (tertiles) on the basis of model $1(n=12,357)$;

Model 3 added serum calcium (tertiles) on the basis of model $1(n=12,264)$;

Model 4 added serum magnesium (tertiles) on the basis of model $1(n=12,362)$;

Model 5 added serum zinc (tertiles) on the basis of model $1(n=12,362)$;

Model 6 added serum phosphorus (tertiles) on the basis of model $1(n=12,264)$

*Three right knees with K-L 4 grade were excluded for analysis (data from the contralateral knees were retained)

$\mathrm{N}$, number; $\mathrm{Cl}$, confidence interval 


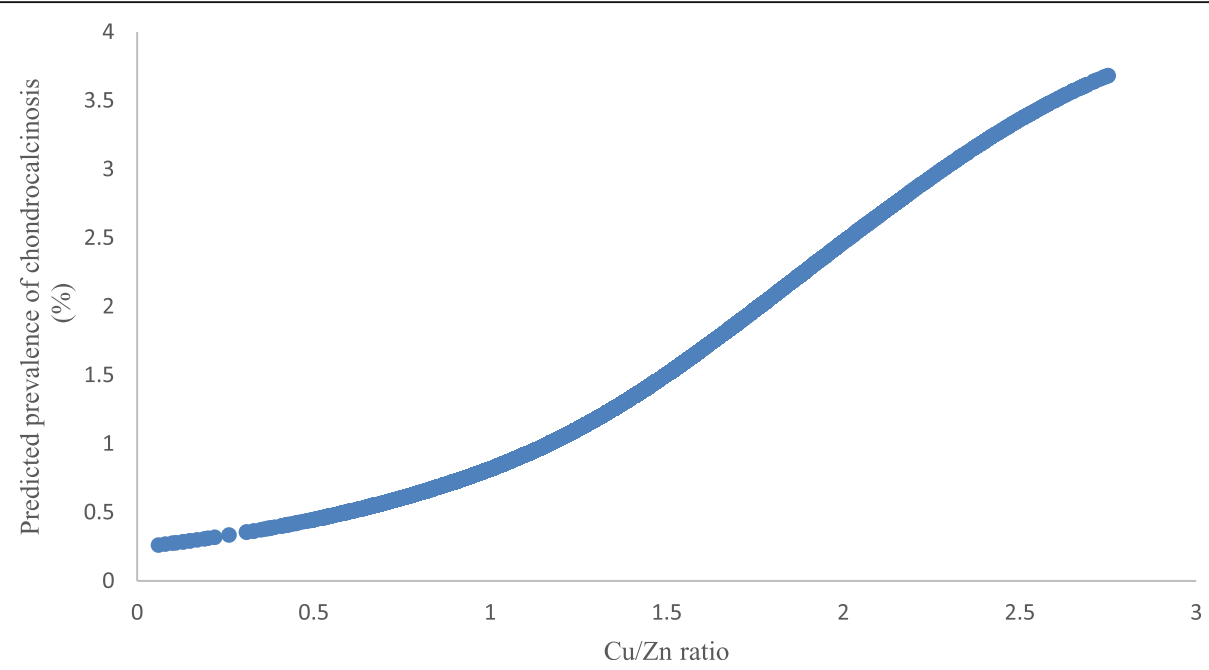

Fig. 3 Association between Cu/Zn ratio and predictive prevalence of chondrocalcinosis. Cu/Zn ratio, the ratio of serum copper to zinc concentrations

of the most typical features of chondrocalcinosis, and it can mediate tissue damage through the inflammatory mechanism [1, 2]. Extracellular trap release can be increased in human neutrophils activated by microcrystals, and the NALP3 inflammasome is induced once the calcium pyrophosphate crystals are deposited [9, 22]. In addition, calcium pyrophosphate crystals can directly catabolize chondrocytes and synoviocytes, resulting in the production of destructive matrix metalloproteinases and prostaglandins, which are both of great importance in the process of inflammatory response $[23,40]$. Thus, the inflammatory response may explain, at least in part, the significant associations between the serum zinc and copper concentrations and the prevalence of chondrocalcinosis.
$\mathrm{Cu} / \mathrm{Zn}$ ratio reflects the balance between copper and zinc in the human body. Rather than a simple nutritional indicator, previous studies showed that it could also be a potential biomarker of inflammatory response and oxidative stress [21, 41]. Moreover, it has been reported to be positively correlated with disability and mortality in elderly subjects aged 70 years and above [21]. The present study showed that lower $\mathrm{Cu} / \mathrm{Zn}$ ratio is associated with a lower prevalence of knee chondrocalcinosis, which also assessed the robustness of our findings of the associations between serum zinc and copper concentrations and the prevalence of chondrocalcinosis, to some extent.

Several advantages of this study are noteworthy. First of all, a large sample size $(n=12,362)$ of this first study

Table 4 Association between Cu/Zn ratio and knee chondrocalcinosis $(n=12,362)$

\begin{tabular}{|c|c|c|c|c|}
\hline & \multicolumn{3}{|c|}{ Tertiles of $\mathrm{Cu} / \mathrm{Zn}$ ratio } & \multirow{2}{*}{$\begin{array}{l}P \text { for } \\
\text { trend }\end{array}$} \\
\hline & $1(\leq 1.07)$ & $2(1.08-1.38)$ & $3(\geq 1.39)$ & \\
\hline \multicolumn{5}{|l|}{ Total } \\
\hline Knee chondrocalcinosis (\%) & 0.7 & 1.0 & 2.1 & - \\
\hline$N$ for knee ${ }^{a}$ & 8158 & 8406 & 8157 & - \\
\hline Model 1 (95\% Cl) & 1.00 (reference) & $1.02(0.61,1.69)$ & $2.23(1.38,3.59)$ & $<0.001$ \\
\hline Model 2 (95\% Cl) & 1.00 (reference) & $1.00(0.60,1.67)$ & $2.12(1.31,3.42)$ & $<0.001$ \\
\hline Model 3 (95\% Cl) & 1.00 (reference) & $1.03(0.62,1.72)$ & $2.27(1.40,3.68)$ & $<0.001$ \\
\hline Model 4 (95\% Cl) & 1.00 (reference) & $1.03(0.62,1.71)$ & $2.26(1.41,3.63)$ & $<0.001$ \\
\hline Model 5 (95\% Cl) & 1.00 (reference) & $1.01(0.61,1.68)$ & $2.20(1.36,3.55)$ & $<0.001$ \\
\hline
\end{tabular}

Model 1 included age (40-49, 50-59, 60-69, $\geq 70$ years), body mass index $\left(<28, \geq 28 \mathrm{~kg} / \mathrm{m}^{2}\right)$ and sex $(n=12,362)$;

Model 2 added serum iron (tertiles) on the basis of model $1(n=12,357)$;

Model 3 added serum calcium (tertiles) on the basis of model $1(n=12,264)$;

Model 4 added serum magnesium (tertiles) on the basis of model $1(n=12,362)$;

Model 5 added serum phosphorus (tertiles) on the basis of model $1(n=12,264)$

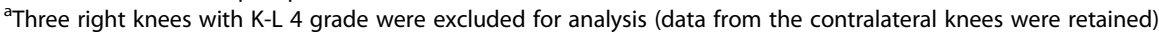

$\mathrm{N}$ number, $\mathrm{Cl}$ confidence interval, $\mathrm{Cu} / \mathrm{Zn}$ ratio the ratio of serum copper to zinc concentrations 
investigating the association between serum zinc and copper concentrations and $\mathrm{Cu} / \mathrm{Zn}$ ratio and knee chondrocalcinosis guaranteed that our findings are likely to be of a low occasionality. Second, the serum zinc, copper concentrations and $\mathrm{Cu} / \mathrm{Zn}$ ratio are respectively correlated with the prevalence of chondrocalcinosis in a doseresponse manner. This observation has important implications for both zinc and copper as trace elements and for the disease of chondrocalcinosis itself, suggesting that there may be correlations between these two elements and the pathogenesis of chondrocalcinosis.

However, this study is also involved with several caveats. First, we cannot draw a causal relationship between the serum zinc and copper concentrations and $\mathrm{Cu} / \mathrm{Zn}$ ratio and the prevalence of chondrocalcinosis due to the cross-sectional design. Nevertheless, as no previous research has investigated the associations between these two elements and chondrocalcinosis, the value of this study should not be diminished. Second, other views of the knee (such as lateral or skyline) were not used to in our study ascertain radiographic chondrocalcinosis; thus, the prevalence of radiographic chondrocalcinosis might be underestimated. Third, the synovial fluid (taken from the joint) test should be more sensitive and specific than radiographs for detecting crystals, and some of the articular calcium pyrophosphate depositions may be too small to be detected on radiographs; thus, our estimation of the prevalence of knee chondrocalcinosis is likely to be underestimated.

\section{Conclusions}

The present study observed that higher serum zinc concentrations, lower serum copper concentrations or lower $\mathrm{Cu} / \mathrm{Zn}$ ratio are associated with a lower prevalence of knee chondrocalcinosis in a dose-response relationship manner.

\section{Supplementary information}

Supplementary information accompanies this paper at https://doi.org/10. 1186/s12891-020-3121-z.

Additional file1. Measuring methods and reliability data of potential confounders.

\section{Abbreviations}

3,5-diBr-PAESA: 4-(3,5-dibromo-2-pyridylazo)-N-ethyl-N-(3-sulfopropyl) aniline; 5-Br-PAPS: 2-(5-Bromo-2-pyridylazo)-5-[N-propyl-N-(3-sulfopropyl) amino] phenol; BMI: Body mass index; Cl: Confidence interval; $\mathrm{Cu} / \mathrm{Zn}$ ratio: The ratio of serum copper to zinc concentrations.; KL: Kellgren-Lawrence;

OAl: Osteoarthritis Initiative; OR: Odds ratio

\section{Acknowledgements}

The authors appreciate the support of Orthopedics Research Institute of Xiangya Hospital.

\section{Authors' contributions}

DXX had full access to the data in the study and take responsibility for the integrity of the data and the accuracy of the data analysis. HYH and YLW conceived the study. $\mathrm{HYH}$ and $\mathrm{YLW}$ were responsible for conception and design of the study and drafted the manuscript. ZDY, XD, TY and GHL contributed to data collection. TY and YLW contributed to assessment of radiographs. ZDY contributed to preparation and data analysis. $\mathrm{HL}$ and $\mathrm{GHL}$ contributed to revision of the manuscript. All the authors contributed to the interpretation of the data and critically reviewed the manuscript for publication. All authors read and approved the final manuscript.

\section{Funding}

This work was supported by the Innovation Foundation of the Central South University for Postgraduate (2018zzts045), the National Natural Science Foundation of China (81772413), the Scientific Research Project of Science and Technology Office of Hunan Province (2017TP1005), the Key Research and Development Program of Hunan Province (2018SK2070, 2018SK2071), the Xiangya Clinical Big Data System Construction Project of Central South University (45), the Clinical Scientific Research Foundation of Xiangya Hospital, Central South University (2015 L03).

Availability of data and materials

Data can be requested from the corresponding author.

\section{Ethics approval and consent to participate}

This study was approved by the Ethics Committee of Xiangya Hospital, Central South University (reference numbers: 201312459), and written informed consent was obtained from all study participants.

\section{Consent for publication}

Not applicable.

\section{Competing interests}

The authors declare that they have no competing interest.

\section{Author details}

'Department of Orthopaedics, Xiangya Hospital, Central South University, \#87 Xiangya Road, Changsha 410008, Hunan Province, China. ${ }^{2}$ Department of Epidemiology and Health Statistics, Xiangya School of Public Health, Central South University, Changsha, Hunan, China. ${ }^{3}$ Health Management Center, Xiangya Hospital, Central South University, Changsha, Hunan, China. ${ }^{4}$ Hunan Engineering Research Center of Osteoarthritis, Changsha, Hunan, China. ${ }^{5}$ Hunan Key Laboratory of Joint Degeneration and Injury, Changsha, Hunan, China. ${ }^{6}$ National Clinical Research Center of Geriatric Disorders, Xiangya Hospital, Central South University, Changsha, Hunan, China.

Received: 21 April 2019 Accepted: 7 February 2020

Published online: 12 February 2020

\section{References}

1. Rosenthal AK, Ryan LM. Calcium pyrophosphate deposition disease. N Engl J Med. 2016;374:2575-84.

2. Abhishek A, Doherty M. Pathophysiology of articular chondrocalcinosis—role of ANKH. Nat Rev Rheumatol. 2011;7:96-104.

3. Abhishek A. Calcium pyrophosphate deposition disease: a review of epidemiologic findings. Curr Opin Rheumatol. 2016;28(2):133-9.

4. Bong D, Bennett R. Pseudogout mimicking systemic disease. JAMA. 1981; 246:1438-40.

5. Kohn NN, Hughes RE, McCarty DJ, Faires JS. The significance of calcium phosphate crystals in the synovial fluid of arthritic patients: the "pseudogout syndrome". II. Identification of crystals. Ann Intern Med. 1962; 56:738-45.

6. Doll NJ, Jackson FN. Acute pseudogout simulating septic arthritis. JAMA. 1979;242:1768.

7. Musacchio E, Ramonda R, Perissinotto E, Sartori L, Hirsch R, Punzi L, Zambon S, Corti MC, Baggio G, Manzato E, Doria A, Crepaldi G. The impact of knee and hip chondrocalcinosis on disability in older people: the ProVA study from northeastern Italy. Ann Rheum Dis. 2011;70(11):1937-43.

8. Abhishek A, Neogi T, Choi H, Doherty M, Rosenthal AK, Terkeltaub R. Review: unmet needs and the path forward in joint disease associated with calcium pyrophosphate crystal deposition. Arthritis Rheumatol. 2018;70(8): 1182-91.

9. Martinon F, Pétrilli V, Mayor A, Tardivel A, Tschopp J. Gout-associated uric acid crystals activate the NALP3 inflammasome. Nature. 2006:440:237-41. 
10. Muehleman C, Li J, Aigner T, Rappoport L, Mattson E, Hirschmugl C, Masuda $K$, Rosenthal AK. Association between crystals and cartilage degeneration in the ankle. J Rheumatol. 2008;35:1108-17.

11. Maggini S, Wintergerst ES, Beveridge S, Hornig DH. Selected vitamins and trace elements support immune function by strengthening epithelial barriers and cellular and humoral immune responses. Br J Nutr. 2007;98: S29-35

12. Mocchegiani E, Costarelli L, Giacconi R, Piacenza F, Basso A, Malavolta M. Micronutrient ( $\mathrm{Zn}, \mathrm{Cu}, \mathrm{Fe}$ )-gene interactions in ageing and inflammatory agerelated diseases: implications for treatments. Ageing Res Rev. 2012:11:297-319.

13. Mariani E, Cattini L, Neri S, Malavolta M, Mocchegiani E, Ravaglia G, Facchini A. Simultaneous evaluation of circulating chemokine and cytokine profiles in elderly subjects by multiplex technology: relationship with zinc status. Biogerontology. 2006;7:449-59.

14. Kim CH, Park JY, Kim JY, Choi CS, Kim Yl, Chung YE, Lee MS, Hong SK, Lee $\mathrm{KU}$. Elevated serum ceruloplasmin levels in subjects with metabolic syndrome: a population-based study. Metabolism. 2002;51(7):838-42.

15. Leone N, Courbon D, Ducimetiere P, Zureik M. Zinc, copper, and magnesium and risks for all-cause, Cancer, and cardiovascular mortality. Epidemiology. 2006;17:308-14.

16. Mocchegiani E, Giacconi R, Malavolta M. Zinc signalling and subcellular distribution: emerging targets in type 2 diabetes. Trends Mol Med. 2008;14: 419-28.

17. Aguilar MV, Saavedra P, Arrieta FJ, Mateos CJ, González MJ, Meseguer I, Martínez-Para MC. Plasma mineral content in type-2 diabetic patients and their association with the metabolic syndrome. Ann Nutr Metab. 2007;51:402-6.

18. Barnham KJ, Bush Al. Metals in Alzheimer's and Parkinson's diseases. Curr Opin Chem Biol. 2008;12:222-8.

19. Socha K, Karpinska E, Kochanowicz J, Soroczynska J, Jakoniuk M, Wilkiel M, Mariak ZD, Borawska MH. Dietary habits; concentration of copper, zinc, and Cu-to-Zn ratio in serum and ability status of patients with relapsingremitting multiple sclerosis. Nutrition. 2017:39-40:76-81.

20. Wacewicz M, Socha K, Soroczynska J, Niczyporuk M, Aleksiejczuk P, Ostrowska J, Borawska MH. Selenium, zinc, copper, $\mathrm{cu} / \mathrm{Zn}$ ratio and total antioxidant status in the serum of vitiligo patients treated by narrow-band ultraviolet-B phototherapy. J Dermatolog Treat. 2018;29(2):190-5.

21. Malavolta M, Giacconi R, Piacenza F, Santarelli L, Cipriano C, Costarelli L, Tesei S, Pierpaoli S, Basso A, Galeazzi R, Lattanzio F, Mocchegiani E. Plasma copper/zinc ratio: an inflammatory/nutritional biomarker as predictor of allcause mortality in elderly population. Biogerontology. 2010;11(3):309-19.

22. Pang L, Hayes CP, Buac K, Yoo D-G, Rada B. Pseudogout-associated inflammatory calcium pyrophosphate dihydrate microcrystals induce formation of neutrophil extracellular traps. J Immunol. 2013;190:6488-500.

23. Liu-Bryan R, Pritzker K, Firestein GS, Terkeltaub R. TLR2 signaling in chondrocytes drives calcium pyrophosphate dihydrate and monosodium urate crystal-induced nitric oxide generation. J Immunol. 2005;174:5016-23.

24. Zeng C, Wei J, Terkeltaub R, Yang T, Choi HK, Wang Y-L, Xie D-X, Hunter DJ, Zhang Y, Li H, Cui Y, Li L-J, Lei G-H. Dose-response relationship between lower serum magnesium level and higher prevalence of knee chondrocalcinosis. Arthritis Res Ther. 2017;19:236

25. Zeng C, Wei J, Li H, Yang T, Zhang F-J, Pan D, Xiao Y-B, Yang T-B, Lei G-H. Relationship between serum magnesium concentration and radiographic knee osteoarthritis. J Rheumatol. 2015:42:1231-6.

26. Wang Y, Wei J, Zeng C, Yang T, Li H, Cui Y, Xie D, Xu B, Liu Z, Li J, Jiang S, Lei G. Association between serum magnesium concentration and metabolic syndrome, diabetes, hypertension and hyperuricaemia in knee osteoarthritis: a cross-sectional study in Hunan Province, China. BMJ open. 2018;8:e019159.

27. Kellgren JH, Lawrence JS. Radiological assessment of osteo-arthrosis. Ann Rheum Dis. 1957:16:494-502

28. Makino T, Saito M, Horiguchi D, Kina K. A highly sensitive colorimetric determination of serum zinc using water-soluble pyridylazo dye. Clin Chim Acta. 1982;120(1):127-35.

29. Homsher R, Zak B. Spectrophotometric investigation of sensitive complexing agents for the determination of zinc in serum. Clin Chem. 1985; 31(8):1310-3.

30. Kimura S, lyama S, Yamaguchi Y, Hayashi S, Fushimi R, Amino N. New enzymatic assay with urea amidolyase for determining potassium in serum. Ann Clin Biochem. 1997:34(Pt 4):384-8.

31. Abhishek A, Doherty S, Maciewicz R, Muir K, Zhang W, Doherty M. Chondrocalcinosis is common in the absence of knee involvement. Arthritis Res Ther. 2012;14:R205
32. Zhang Y, Glynn RJ, Felson DT. Musculoskeletal disease research: should we analyze the joint or the person? J Rheumatol. 1996:23:1130-4

33. Hastie T, Tibshirani R. Generalized additive models for medical research. Stat Methods Med Res. 1995:4(3):187-96.

34. Muzzioli M, Stecconi R, Moresi R, Provinciali M. Zinc improves the development of human CD34+ cell progenitors towards NK cells and increases the expression of GATA-3 transcription factor in young and old ages. Biogerontology. 2009;10:593-604.

35. Mocchegiani E, Muzzioli M, Giacconi R, Cipriano C, Gasparini N, Franceschi C, Gaetti R, Cavalieri E, Suzuki H. Metallothioneins/PARP-1/IL-6 interplay on natural killer cell activity in elderly: parallelism with nonagenarians and old infected humans. Effect of zinc supply. Mech Ageing Dev. 2003;124:459-68.

36. Mariani E, Mangialasche F, Feliziani FT, Cecchetti R, Malavolta M, Bastiani P, Baglioni M, Dedoussis G, Fulop T, Herbein G, Jajte J, Monti D, Rink L, Mocchegiani E, Mecocci P. Effects of zinc supplementation on antioxidant enzyme activities in healthy old subjects. Exp Gerontol. 2008;43:445-51.

37. Yasui K, Kobayashi N, Yamazaki T, Agematsu K, Matsuzaki S, Ito S, Nakata S, Baba A, Koike K. Superoxide dismutase (SOD) as a potential inhibitory mediator of inflammation via neutrophil apoptosis. Free Radic Res. 2005;39: 755-62.

38. Yasui K, Baba A. Therapeutic potential of superoxide dismutase (SOD) for resolution of inflammation. Inflamm Res. 2006:55:359-63.

39. White C, Lee J, Kambe T, Fritsche K, Petris MJ. A role for the ATP7A coppertransporting ATPase in macrophage bactericidal activity. J Biol Chem. 2009; 284:33949-56

40. Reuben PM, Wenger L, Cruz M, Cheung HS. Induction of matrix metalloproteinase-8 in human fibroblasts by basic calcium phosphate and calcium pyrophosphate dihydrate crystals: effect of phosphocitrate. Connect Tissue Res. 2001:42:1-12.

41. Mezzetti A, Pierdomenico SD, Costantini F, Romano F, De Cesare D, Cuccurullo F, Imbastaro T, Riario-Sforza G, Di Giacomo F, Zuliani G, Fellin R. Copper/zinc ratio and systemic oxidant load: effect of aging and agingrelated degenerative diseases. Free Radic Biol Med. 1998;25(6):676-81.

\section{Publisher's Note}

Springer Nature remains neutral with regard to jurisdictional claims in published maps and institutional affiliations.
Ready to submit your research? Choose BMC and benefit from:

- fast, convenient online submission

- thorough peer review by experienced researchers in your field

- rapid publication on acceptance

- support for research data, including large and complex data types

- gold Open Access which fosters wider collaboration and increased citations

- maximum visibility for your research: over $100 \mathrm{M}$ website views per year

At $\mathrm{BMC}$, research is always in progress.

Learn more biomedcentral.com/submissions 